\title{
SISTEM KONTROL MESIN PENUKARAN UANG KERTAS RUPIAH BERBASIS PENGOLAHAN CITRA DAN RASPBERRY PI
}

\author{
Abdul Jalil \\ abdul.jalil.fw@gmail.com \\ STMIK Handayani Makassar
}

\begin{abstract}
Abstrak
Penelitian ini bertujuan untuk membangun sebuah sistem kontrol mesin penukaran uang kertas rupiah dari nominal besar ke nominal kecil berbasis pengolahan citra dan Raspberry Pi. Metode penukaran uang dilakukan dengan cara mendeteksi keaslian uang, deteksi nominal uang, dan jumlah penukaran uang. Keaslian uang dideteksi dari invisible image uang kertas rupiah dan nominal uang dideteksi berdasarkan warna uang. Teknik deteksi keaslian dan nominal uang adalah menggunakan pengolahan citra yang diproses pada Raspberry $\mathrm{Pi}$. Algoritma yang digunakan untuk medeteksi keaslian dan nominal uang adalah algoritma template color dan algoritma untuk penukaran uang adalah algoritma greedy. Hasil dari penelitian ini adalah sistem dapat mendeteksi keaslian dan nominal uang kertas Rp.100.000, Rp.50.000, dan Rp.20.000 kemudian menukarkannya ke nominal uang kecil sesuai dengan pilihan pengguna.
\end{abstract}

Kata Kunci: Uang kertas Rupiah, pengolahan citra, Raspberry Pi.

\begin{abstract}
The research purpose is to build a machine control system for exchange nominal of rupiah's paper money from big nominal to small nominal based on image processing and Raspberry Pi. The method for money exchange is detecting the authenticity of money, nominal of money, and amount of money exchange. The money authenticity was detected by the invisible image and nominal of money was detected by money color. Technique for detection the authenticity and nominal of money are using image processing that is processed on the Raspberry $\mathrm{Pi}$. The algorithm used for detecting the authenticity and nominal of money are using template color algorithm and for exchange amount of money using the greedy algorithm. The research result is system able to detect the authenticity and nominal of paper money IDR 100.000 , IDR 50.000, and IDR 20.000 then exchange it with the small nominal of money in accordance with the user choice.
\end{abstract}

Keyword: Rupiah's paper money, image processing, Raspberry Pi.

\section{Pendahuluan}

Kebutuhan masyarakat dalam menukar uang dari nominal besar ke nominal kecil merupakan sesuatu hal yang banyak ditemukan pada saat-saat tertentu seperti pada saat hari raya keagamaan dan hari besar lainnya. Selain itu masyarakat juga menginginkan uang nominal kecil untuk keperluan pribadi mereka. Salah satu kendala saat ini adalah sulitnya mencari uang nominal kecil dalam jumlah yang banyak sehingga mengharuskan masyarakat pergi ke Bank atau membelinya pada penyedia jasa penukaran uang nominal kecil.

Bedasarkan permasalahan tersebut maka penulis melakukan penelitian untuk membuat sebuah mesin yang dapat menukarkan uang dari nominal besar ke nominal kecil. Pada penelitian sebelumnya penulis telah melakukan penelitian bagaimana mendesain sebuah mesin penukaran uang dari nominal besar ke nominal kecil [1], bagaimana mendeteksi keaslian uang kertas rupiah menggunakan teknik image processing raspberry pi [2][7] dan bagaimana mendeteksi nominal uang kertas rupiah menggunakan teknik image processing raspberry pi [3]. Pada penelitian ini penulis membangun sebuah mesin yang dapat menukarkan uang kertas rupiah dari nominal besar ke nominal kecil berdasarkan pengembangan penelitian yang telah dilakukan sebelumnya.

\section{Metode Penelitian}

\subsection{Uang kertas Rupiah}

Mata uang Rupiah adalah mata uang resmi Negara Kesatuan Republik Indonesia. Uang merupakan segala sesuatu yang dapat digunakan sebagai alat tukar, sebagai media dalam pembayaran barang-barang, sebagai alat pengukur nilai dan juga berfungsi sebagai alat penimbun kekayaan. Uang juga memiliki fungsi sebagai satuan hitung (unit of account) karena dapat menunjukkan nilai barang atau jasa yang diperjual belikan [4]. Dalam perancangan desain uang kertas rupiah terdapat beberapa aspek yang diterapkan, seperti visualisasi uang yang berhubungan 
dengan arsitektur dan gayanya, gambar uang berhubungan dengan nilai kebudayaan, dan keamanan uang berhubungan dengan keaslian uang tersebut [5].

Pada penelitian ini jenis uang rupiah yang dapat ditukar adalah uang kertas Rupiah dari nominal besar ke nominal kecil yaitu Rp.100.000, Rp.50.000 dan Rp.20.000, nominal uang tersebut dapat ditukar dengan nominal uang kecil Rp.20.000, Rp.10.000, Rp.5.000, Rp.2.000 dan Rp.1.000. Pada penerapannya pengguna dapat memilih jumlah nominal uang kecil yang ingin ditukar. Pada mesin penukaran uang terdapat tombol untuk memilih berapa jumlah uang yang ingin ditukar dari nominal besar ke nominal kecil sehingga sistem yang dibangun sangat fleksibel dalam penukaran uangnya.

\subsection{Mendeteksi keaslian uang kertas Rupiah}

Metode yang digunakan untuk mendeteksi keaslian uang adalah dengan membaca nilai warna pada invisible image uang kertas rupiah menggunakan algoritma template color. Invisible image adalah gambar tidak tampak yang ada pada uang kertas rupiah asli dan hanya akan terlihat jika diberi cahaya ultraviolet. Algoritma template color adalah teknik pengolahan citra untuk membandingkan nilai warna yang ada pada gambar dengan nilai referensi sistem. Pada proses pengolahan citra, gambar invisible image akan di filter menggunakan teknik thresholding image [7] kemudian diproses menggunakan algoritma template color untuk membandingkan nilai warna RGB serta thresholding yang ada pada sistem.

Terdapat beberapa teknik untuk mendeteksi keaslian uang kertas rupiah, salah satunya adalah dengan mendeteksi gambar invisible image yang ada pada uang kertas rupiah. Cara untuk memunculkan gambar invisible image adalah dengan menggunakan cahaya ultraviolet, yaitu uang kertas diletakkan dibawah cahaya ultraviolet, jika invisible image muncul maka uang tersebut asli, jika tidak maka uang tersebut palsu [2].
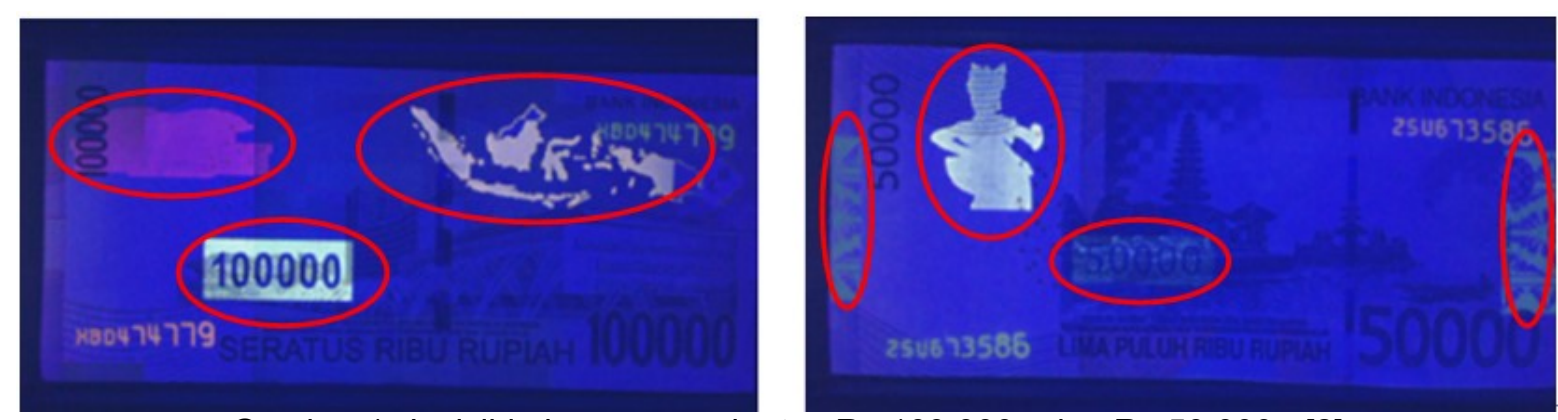

Gambar 1. Invisible image uang kertas Rp.100.000,- dan Rp.50.000,- [2]

\subsection{Mendeteksi nominal uang kertas Rupiah}

Metode yang digunakan untuk mendeteksi nominal uang kertas rupiah adalah berdasarkan warna uang menggunakan algortima template color. Uang kertas rupiah akan diberi cahaya led kemudian kamera mengambil gambar dari uang tersebut. Gambar yang dihasilkan kemudian diproses menggunakan algoritma template color yang dibandingkan dengan nilai referensi warna RGB dan threshold dari setiap nominal uang kertas rupiah. Dalam penelitian ini hanya tiga jenis uang kertas Rupiah yang dideteksi dan setiap nominal uang tersebut mempunyai warna yang berbeda-beda yaitu uang Rp.100.000,- berwarna merah, Rp.50.000,- berwarna biru dan Rp.20.000,- berwarna hijau [3].

\subsection{Raspberry Pi}

Raspberry $\mathrm{Pi}$ merupakan salah satu jenis Mikrokomputer yang banyak digunakan untuk keperluan penelitian dan pendidikan. Harganya yang murah, powerfull, dan bentuknya yang kecil seperti kartu ATM membuat Rasberry Pi banyak diminati oleh para peneliti dan pengembang dibidang sistem kontrol dan Internet of Things. Fitur-fitur yang ada pada Raspberry $\mathrm{Pi}$ seperti Processor dengan kecepatan hingga $1,2 \mathrm{GHz}$, RAM $1 \mathrm{GHz}$, LAN, koneksi wifi, bloetooth, HDMI output, audio, USB port dan dilengkapi dengan fasilitas GPIO pin yang berfungsi sebagai pin $1 / O$ yang akan terhubung ke device, sensor dan sistem kontrol.

Terdapat beberapa jenis Raspberry Pi yang telah diproduksi, seperti Raspberry Pi Model A, Raspberry Pi Model B, Raspberry Pi 2, Raspberry Pi 3 dan Raspberry Pi Zero. Adapun jenis Raspberry Pi yang digunakan pada penelitian ini adalah Raspberry Pi model B+.

\subsection{Sistem penukaran nominal uang Rupiah.}

Berikut adalah alur sistem penukaran nominal uang kertas rupiah: 
1) Pengguna memasukkan nominal uang yang ingin ditukar (Rp.100.000, Rp.50.000 atau Rp.20.000).

2) Sistem mendeteksi keaslian uang, jika uang memiliki invisible image maka uang tersebut asli, jika tidak maka uang palsu.

3) Jika uang asli maka sistem akan melanjutkan membaca nominal uang, jika palsu maka sistem akan berhenti.

4) Jika uang asli maka sistem akan membaca nominal uang berdasarkan warnanya, Rp.100.000 warna merah, Rp.50.000 warna biru, dan Rp.20.000 warna hijau.

5) Pengguna memilih jumlah nominal uang kecil yang akan ditukarkan dengan cara menekan tombol pilihan yang ada pada mesin.

6) Mesin akan mengeluarkan sejumlah nominal uang kertas rupiah sesuai dengan pilihan pengguna.

Dalam penelitian ini teknik pengolahan citra yang dilakukan adalah dengan cara thresholding image yang diambil berdasarkan binary image kemudian diubah menjadi nilai bit (0 dan 1). Hasil dari nilai bit tersebut kemudian dikirim ke pin GPIO untuk mengontrol device yang ada pada mesin [3]. Adapun algoritma yang digunakan untuk penukaran uang pada mesin ini adalah algoritma greedy [6].

\section{Hasil dan Pembahasan}

\subsection{Mesin penukaran uang kertas Rupiah}

Berdasarkan perancangan yang ada, mesin penukaran uang yang dirancang dapat menukarkan uang dari nominal besar ke nominal kecil. Adapun bahan yang digunakan untuk membuat mesin ini adalah alumunium, tripleks dan acrylic. Berikut adalah gambar hasil penelitian mesin penukaran nominal uang kertas rupiah.

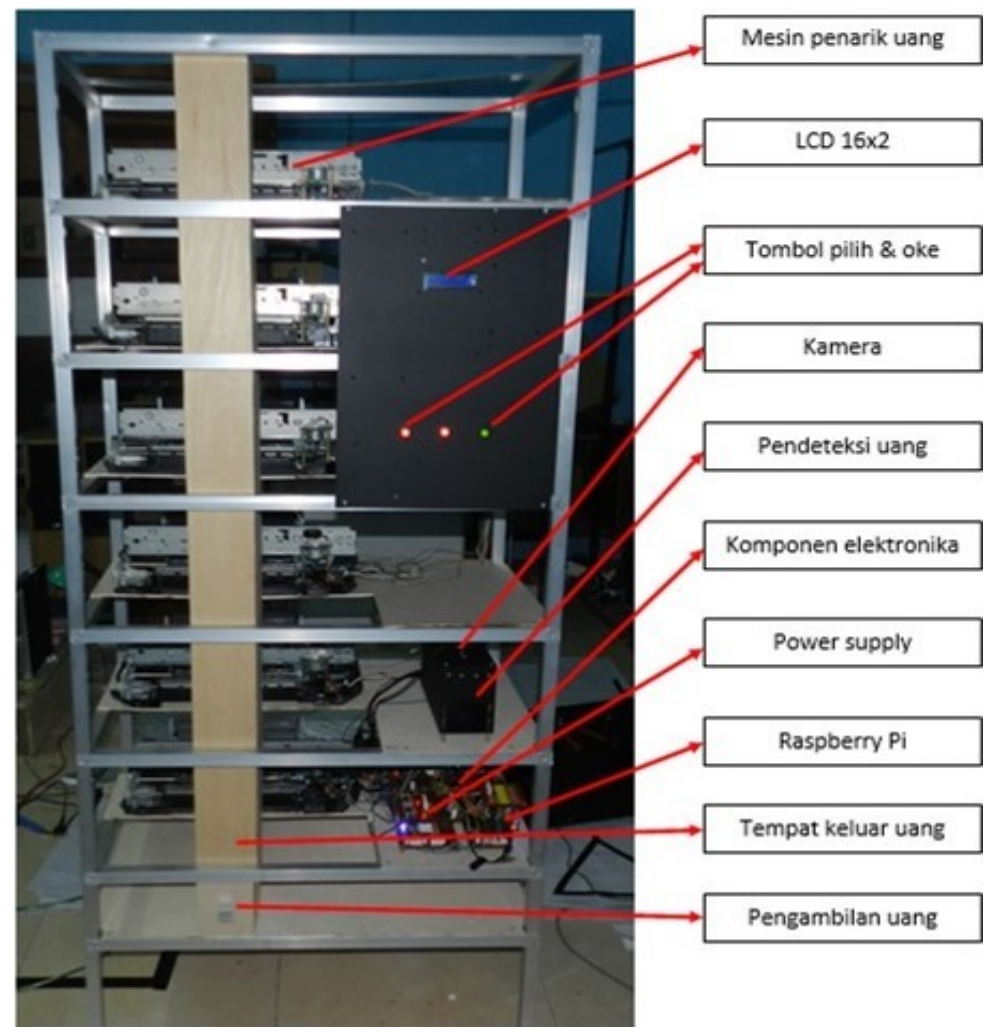

Gambar 2. Mesin penukaran nominal uang kertas Rupiah

Sistem kontrol pada mesin terbuat dari beberapa bagian yang saling terhubung yaitu kamera untuk mengambil gambar uang, cahaya ultraviolet untuk menampilkan invisible image uang, cahaya led digunakan saat deteksi nominal uang, mikrokontroler untuk mengontrol relay dan motor penarik uang kertas, Raspberry Pi untuk proses pengolahan citra, komponen elektronika (power supply, driver motor, driver relay), dan mesin penarik uang. Semua komponen tersebut disatukan hingga terbentuk suatu sistem penukaran nominal uang dengan teknik pengenalan pola citra. 


\subsection{Deteksi keaslian uang}

Pada penelitian ini uang kertas yang digunakan adalah Rp.100.000, Rp.50.000, dan Rp.20.000. Nominal uang tersebut terbilang besar dan paling banyak ditukarkan oleh masyarakat. Berdasarkan hasil penelitian deteksi keaslian uang terdapat perbedaan nilai RGB antara nominal uang yang satu dengan yang lainnya, namun dalam penelitian ini telah didapatkan satu nilai RGB dan threshold yang dapat mendeteksi keaslian uang dengan menggunakan algoritma template color. Berikut adalah hasil pengolahan citra mendeteksi keaslian uang kertas rupiah.
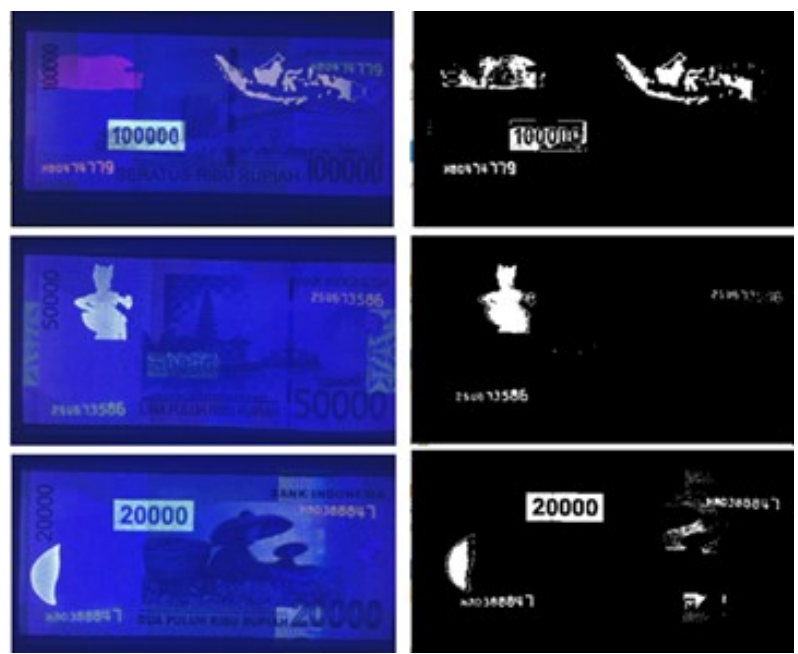

Gambar 3. Hasil deteksi keaslian uang kertas Rp.100.000, Rp.50.000, dan Rp. 20.000.

Selain medeteksi keaslian uang, peneliti juga telah melakukan uji coba deteksi invisible image pada uang palsu menggunakan cahaya ultraviolet. Jenis uang palsu yang diuji coba adalah menggunakan uang kertas duplikat yang dicetak menggunakan printer inkjet. Berdasarkan hasil uji coba tersebut sistem tidak mendeteksi adanya invisible image sehingga hasil pengolahan citra yang ditampilkan adalah berwarna hitam. Berikut adalah gambar hasil pengolahan citra deteksi uang palsu.
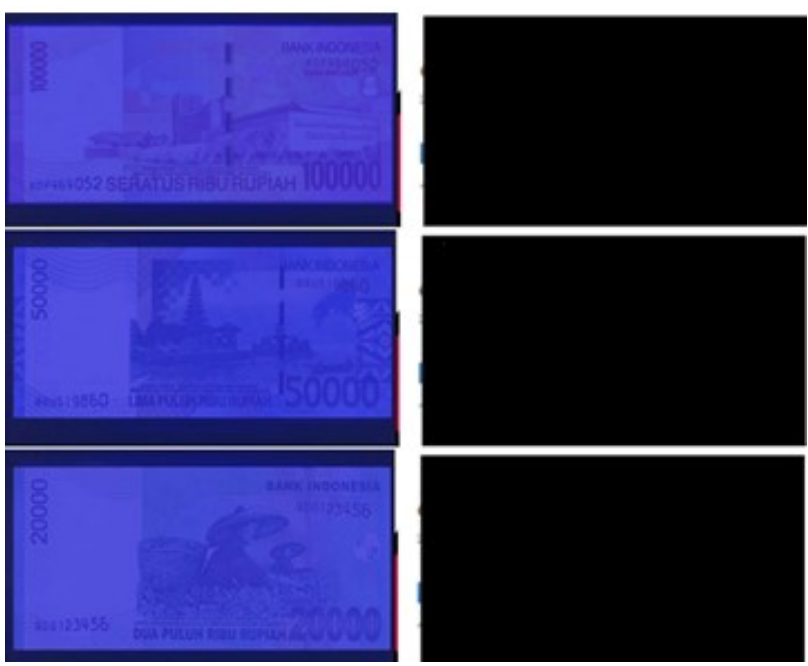

Gambar 4. Hasil deteksi uang kertas palsu Rp.100.000, Rp.50.000, dan Rp. 20.000

Pada sistem deteksi uang asli dan palsu terdapat nilai RGB dan threshold yang digunakan untuk memastikan apakah uang tersebut asli atau tidak. Berikut adalah tabel nilai RGB dan threshold yang digunakan untuk mendeteksi keaslian uang kertas rupiah.

Tabel 1. Hasil penelitian mendeteksi keaslian uang dengan 10 kali pengujian.

\begin{tabular}{|c|c|c|c|c|c|}
\hline \multirow[b]{2}{*}{ Uang } & \multirow{2}{*}{$\begin{array}{c}\text { Nilai } \\
\text { RGBT }\end{array}$} & \multirow{2}{*}{$\begin{array}{c}\text { Asli / } \\
\text { Tidak Asli }\end{array}$} & \multicolumn{2}{|c|}{ Pengujian $10 x$} & \multirow{2}{*}{$\begin{array}{c}\text { Tingkat } \\
\text { Keberhasilan }\end{array}$} \\
\hline & & & Deteksi & Tdk Deteksi & \\
\hline \multirow{2}{*}{ Rp.20.000 } & $R=140$ & \multirow{2}{*}{ Asli } & \multirow{2}{*}{10} & \multirow{2}{*}{-} & \multirow{2}{*}{$100 \%$} \\
\hline & $G=160$ & & & & \\
\hline
\end{tabular}


ILKOM Jurnal IImiah Volume 10 Nomor 2 Agustus 2018

\begin{tabular}{|c|c|c|c|c|c|}
\hline & $B=190$ & & & & $100 \%$ \\
\hline & $\mathrm{T}=80$ & I dk Asll & 10 & - & $100 \%$ \\
\hline \multirow{4}{*}{ Rp.50.000 } & $R=130$ & \multirow{2}{*}{ Asli } & \multirow{2}{*}{10} & \multirow{2}{*}{-} & \multirow{2}{*}{$100 \%$} \\
\hline & $G=160$ & & & & \\
\hline & $B=200$ & \multirow{2}{*}{ Tdk Asli } & \multirow{2}{*}{10} & \multirow{2}{*}{-} & \multirow{2}{*}{$100 \%$} \\
\hline & $\mathrm{T}=80$ & & & & \\
\hline \multirow{4}{*}{ Rp.100.000 } & $R=150$ & \multirow{2}{*}{ Asli } & \multirow{2}{*}{10} & \multirow{2}{*}{-} & \multirow{2}{*}{$100 \%$} \\
\hline & $\mathrm{G}=90$ & & & & \\
\hline & $B=175$ & \multirow{2}{*}{ Tdk Asli } & \multirow{2}{*}{10} & \multirow{2}{*}{-} & \multirow{2}{*}{$100 \%$} \\
\hline & $\mathrm{T}=80$ & & & & \\
\hline
\end{tabular}

\subsection{Deteksi nominal uang}

Pada penelitian ini telah berhasil mendeteksi nominal uang kertas Rupiah berdasarkan warna dengan nominal Rp. 20.000,-, Rp. 50.000,-, dan Rp. 100.000,-. Algoritma pemrograman yang digunakan adalah template color dimana proses threshold untuk mendeteksi nominal uang kertas rupiah adalah menggunakan bahasa python yang diolah pada Raspberry Pi. Pada proses threshold bagian utamanya adalah pada pengaturan nilai RGB dan threshold serta pengaturan cahaya yang tetap. Berikut adalah hasil deteksi nominal uang kertas rupiah berdasarkan warna uang.
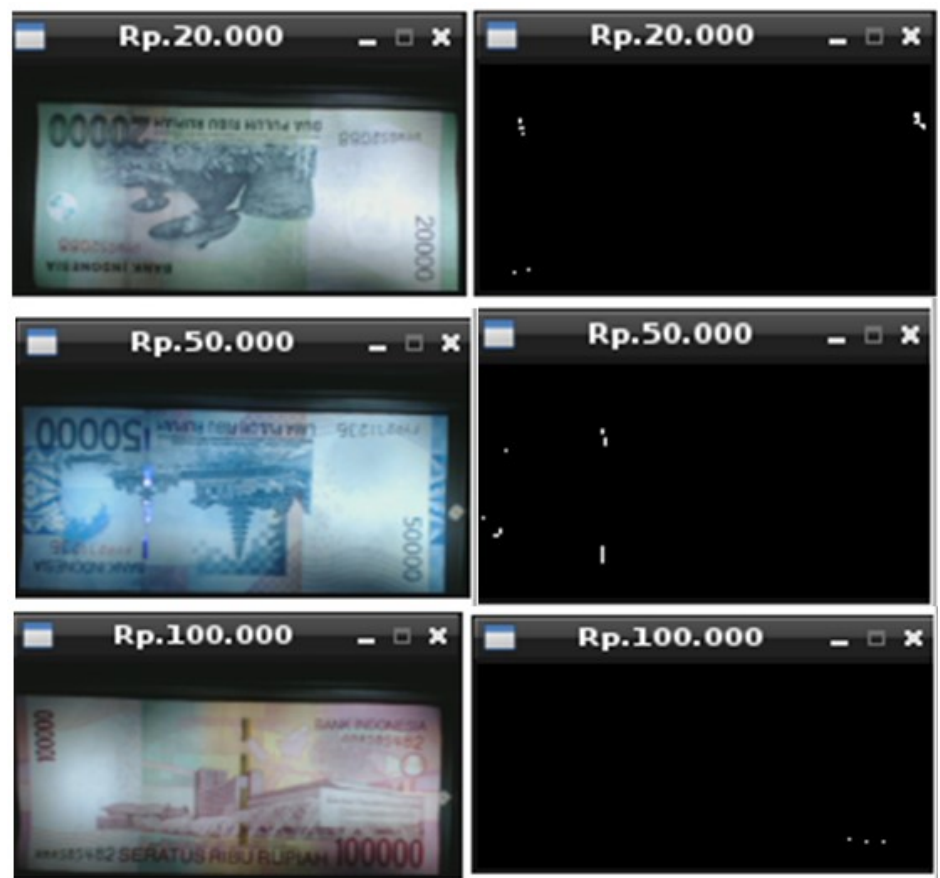

Gambar 5. Hasil deteksi nominal uang Rp.100.000, Rp.50.000, dan Rp. 20.000.

Sistem yang digunakan untuk mendeteksi nominal uang adalah berdasarkan warna uang. Setiap nominal uang memiliki warna yang berbeda-beda, berikut adalah tabel nilai RGB dan threshold untuk mendeteksi nominal uang kertas rupiah.

Tabel 2. Hasil penelitian mendeteksi nominal uang dengan 10 kali pengujian.

\begin{tabular}{|c|c|c|c|c|}
\hline Inna & Nilai & & n $10 x$ & Tingkat \\
\hline Uang & RGBT & Deteksi & Tdk Deteksi & Keberhasilan \\
\hline & $R=35$ & & & \\
\hline$R n 2000$ & $G=140$ & 10 & 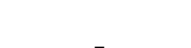 & $100 \%$ \\
\hline Rp.20.000 & $B=60$ & 10 & - & $100 \%$ \\
\hline & $T=50$ & & & \\
\hline & $R=35$ & & & \\
\hline$P n 50000$ & $G=35$ & 10 & & $100 \%$ \\
\hline Rp.50.000 & $B=140$ & 10 & - & $100 \%$ \\
\hline & $T=45$ & & & \\
\hline Rn 100000 & $R=140$ & 10 & 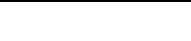 & \\
\hline Rp.100.000 & $G=35$ & 10 & - & $100 \%$ \\
\hline
\end{tabular}




\begin{tabular}{|l|l|l|l|l|}
\hline & $\mathrm{B}=35$ & \multirow{2}{*}{} & \\
\hline & $\mathrm{T}=45$ & & & \\
\hline
\end{tabular}

Berdasarkan tabel 1 dan tabel 2 dapat dilihat bahwa setiap nominal uang mempunyai nilai RGB dan nilai threshold yang berbeda-beda, namun kemampuan sistem dalam mempertahankan nilai-nilai tersebut sangat berpengaruh dengan lups cahaya yang dideteksi oleh kamera. Adapun cahaya yang digunakan untuk mendeteksi keaslian uang adalah cahaya ultraviolet dan cahaya untuk mendeteksi nominal uang adalah cahaya dari lampu led.

\subsection{Penukaran Nominal Uang}

Pada mesin penukaran uang ini pengguna dapat memilih jumlah nominal uang yang ingin ditukar. Terdapat tombol pilih atas, tombol pilih bawah serta tombol oke. Tombol pilih atas dan bawah berfungsi untuk memilih jumlah nominal uang yang ingin ditukar oleh pengguna, setelah itu menekan tombol oke untuk memastikan pilihan. Kelebihan dari mesin penukaran uang ini adalah sifatnya yang fleksibel dalam memilih jenis nominal uang kecil yang akan ditukar, ini berbeda dengan beberapa mesin penukaran uang yang hanya menukarkan nominal uang secara otomatis. Berikut adalah tulisan yang tampak pada LCD mesin ketika pengguna ingin memilih berapa jumlah uang yang akan ditukar.

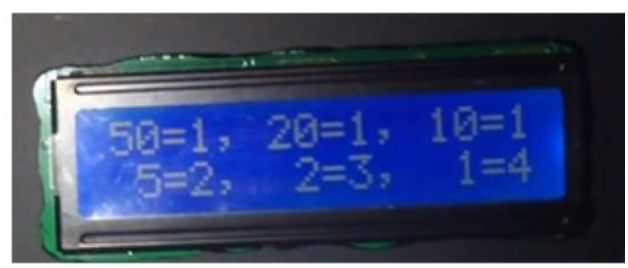

Gambar 6. Tampilan pilihan penukaran nominal uang Rp.100.000 pada LCD mesin.

Dalam penelitian ini nominal uang kecil yang dapat ditukar pada mesin adalah Rp.50.000, Rp.20.000, Rp.10.000, Rp.5000, Rp.2000 dan Rp.1000. Pilihan jumlah nominal uang tersebut dapat dilihat pada tabel 3,4 dan 5 .

Tabel 3. Daftar penukaran nominal uang Rp.100.000,-

\begin{tabular}{|c|c|c|c|c|c|c|}
\hline \multirow{2}{*}{$\begin{array}{l}\text { Nominal } \\
\text { Uang }\end{array}$} & \multicolumn{6}{|c|}{ Pilihan jumlah nominal uang yang dapat ditukar } \\
\hline & Rp.50.000 & Rp.20.000 & Rp.10.000 & Rp.5.000 & Rp.2.000 & Rp.1.000 \\
\hline \multirow{10}{*}{ Rp.100.000 } & 2 & - & - & - & - & - \\
\hline & 1 & 1 & 1 & 4 & - & - \\
\hline & 1 & - & 3 & 4 & - & - \\
\hline & 1 & - & 5 & - & - & - \\
\hline & 1 & 1 & 1 & 2 & 3 & 4 \\
\hline & 1 & 2 & 1 & - & - & - \\
\hline & - & - & 10 & - & - & - \\
\hline & - & 5 & - & - & - & - \\
\hline & - & 3 & 2 & 4 & - & - \\
\hline & - & - & - & - & - & 100 \\
\hline
\end{tabular}

Tabel 4. Daftar penukaran nominal uang Rp.50.000,-

\begin{tabular}{|c|c|c|c|c|c|}
\hline \multirow{3}{*}{$\begin{array}{c}\text { Nominal } \\
\text { Uang }\end{array}$} & \multicolumn{5}{|c|}{ Pilihan jumlah nominal uang yang dapat ditukar } \\
\cline { 2 - 6 } & Rp.20.000 & Rp.10.000 & Rp.5.000 & Rp.2.000 & Rp.1.000 \\
\hline \multirow{4}{*}{ Rp.50.000 } & 2 & 1 & - & - & - \\
\cline { 2 - 6 } & 1 & 2 & 2 & - & - \\
\cline { 2 - 6 } & - & 5 & - & - & - \\
\cline { 2 - 6 } & - & - & 10 & - & - \\
\cline { 2 - 6 } & - & 3 & 4 & - & - \\
\cline { 2 - 6 } & 1 & 3 & - & - & - \\
\cline { 2 - 6 } & 1 & 1 & 2 & - & 10 \\
\cline { 2 - 6 } & - & 4 & - & - & - \\
\hline
\end{tabular}

Tabel 5. Daftar penukaran nominal uang Rp.20.000,-

\begin{tabular}{|c|c|c|c|c|}
\hline \multirow{2}{*}{$\begin{array}{c}\text { Nominal } \\
\text { Uang }\end{array}$} & \multicolumn{4}{|c|}{ Pilihan jumlah nominal uang yang dapat ditukar } \\
\cline { 2 - 5 } & Rp.10.000 & Rp.5.000 & Rp.2.000 & Rp.1.000 \\
\hline Rp.20.000 & 2 & - & - & - \\
\hline
\end{tabular}




\begin{tabular}{|c|c|c|c|c|}
\hline \multirow{4}{*}{} & 1 & 2 & - & - \\
\cline { 2 - 5 } & 1 & - & 5 & - \\
\cline { 2 - 5 } & - & - & 10 & - \\
\cline { 2 - 5 } & 1 & - & - & 10 \\
\cline { 2 - 5 } & - & 4 & - & - \\
\cline { 2 - 5 } & 1 & 1 & - & 5 \\
\cline { 2 - 5 } & - & - & 5 & 10 \\
\hline
\end{tabular}

Berikut adalah tabel pengujian kesuksesan hasil penukaran uang dari nominal besar ke nominal kecil.

Tabel 6. Pengujian hasil kesuksesan mesin penukaran uang.

\begin{tabular}{|c|c|c|c|c|c|c|c|c|}
\hline \multirow{2}{*}{ Percobaan } & \multirow{2}{*}{$\begin{array}{c}\text { Nominal } \\
\text { Uang }\end{array}$} & \multicolumn{6}{|c|}{ Pilihan jumlah nominal uang yang ingin ditukar } & \multirow{2}{*}{ Hasil Penukaran } \\
\hline & & 50.000 & 20.000 & 10.000 & 5.000 & 2.000 & 1.000 & \\
\hline \multirow{3}{*}{1} & Rp.100.000 & 2 & - & - & - & - & - & Rp.50.000 = 2 lembar \\
\hline & Rp.50.000 & - & 2 & 1 & - & - & - & $\begin{array}{l}\text { Rp. } 20.000=2 \text { lembar } \\
\text { Rp. } 10.000=1 \text { lembar }\end{array}$ \\
\hline & Rp.20.000 & - & - & 2 & - & - & - & Rp.10.000 = 2 lembar \\
\hline \multirow{3}{*}{2} & Rp.100.000 & 1 & - & 3 & 4 & - & - & $\begin{array}{l}\text { Rp. } 50.000=1 \text { lembar } \\
\text { Rp. } 10.000=3 \text { lembar } \\
\text { Rp. } 5.000=4 \text { lembar }\end{array}$ \\
\hline & Rp.50.000 & - & - & 5 & - & - & - & Rp. $10.000=5$ lembar \\
\hline & Rp.20.000 & - & - & 1 & - & 5 & - & $\begin{array}{l}\text { Rp. } 10.000=1 \text { lembar } \\
\text { Rp. } 2.000=5 \text { lembar }\end{array}$ \\
\hline \multirow[t]{3}{*}{3} & Rp.100.000 & 1 & 1 & 1 & 2 & 3 & 4 & $\begin{array}{l}\text { Rp.50.000 = } 1 \text { lembar } \\
\text { Rp.20.000 = } 1 \text { lembar } \\
\text { Rp.10.000 = } 1 \text { lembar } \\
\text { Rp.5.000 = } 2 \text { lembar } \\
\text { Rp.2.000 = } 3 \text { lembar } \\
\text { Rp. } 1.000=4 \text { lembar }\end{array}$ \\
\hline & Rp.50.000 & - & - & 3 & 4 & - & - & $\begin{array}{l}\text { Rp. } 10.000=3 \text { lembar } \\
\text { Rp. } 5.000=4 \text { lembar }\end{array}$ \\
\hline & Rp.20.000 & - & - & 1 & - & - & 10 & $\begin{array}{l}\text { Rp. } 10.000=1 \text { lembar } \\
\text { Rp. } 1.000=10 \text { lembar }\end{array}$ \\
\hline \multirow{3}{*}{4} & Rp.100.000 & - & - & 10 & - & - & - & Rp.10.000=10 lembar \\
\hline & Rp.50.000 & - & 1 & 1 & 2 & - & 10 & $\begin{array}{l}\text { Rp. } 20.000=1 \text { lembar } \\
\text { Rp. } 10.000=1 \text { lembar } \\
\text { Rp. } 5.000=2 \text { lembar } \\
\text { Rp. } 1.000=10 \text { lembar }\end{array}$ \\
\hline & Rp.20.000 & - & - & 1 & 1 & - & 5 & $\begin{array}{l}\text { Rp. } 10.000=1 \text { lembar } \\
\text { Rp. } 5.000=1 \text { lembar } \\
\text { Rp. } 1.000=5 \text { lembar }\end{array}$ \\
\hline
\end{tabular}

Berdasarkan hasil pengujian kesuksesan penukaran uang pada tabel 6 dapat dilihat bahwa mesin dapat menukarkan uang dari nominal besar ke nominal kecil dengan tingkat kesuksesan $100 \%$. Tingkat kesuksesan ini sangat bergantung pada pembacaan nominal uang pada mesin. Pengguna dapat memilih dengan bebas berapa jumlah nominal uang kecil yang ingin ditukar. Namun jika pengguna tidak menemukan pilihan jumlah nominal uang kecil yang diinginkan, pengguna dapat memilih jumlah nominal penukaran lainnya yang mendekati dari jumlah penukaran yang diinginkan. Namun dalam pengembangannya, diharapkan mesin ini dapat melayani semua jumlah penukaran nominal uang kecil sesuai dengan pilihan pengguna, yaitu dengan cara mengupgrade sistem penukaran yang ada pada sistem kontrol mesin. Adapun video hasil penelitian penukaran nominal uang dapat dilihat pada youtube [8].

\section{Kesimpulan dan Saran}

Sistem kontrol mesin penukaran uang yang telah dibangun dapat menukarkan uang dari nominal besar ke nominal kecil. Jenis uang yang dapat ditukar adalah uang kertas Rupiah. Mekanisme penukaran uang dilakukan dengan cara mendeteksi keaslian dan nominal uang menggunakan teknik pengolahan citra atau image processing yang di proses oleh Raspberry $\mathrm{Pi}$. Keaslian uang rupiah dideteksi dari gambar invisible image yang ditampilkan menggunakan cahaya ultraviolet sedangkan nominal uang dideteksi berdasarkan warna uang. Dalam penelitian ini nominal uang yang dapat ditukar adalah Rp.100.000, Rp.50.000, dan Rp.20.000, nominal uang tersebut dapat 
ditukar ke nominal Rp.10.000, Rp. 5.000, Rp.2.000 dan Rp. 1.000. Adapun jumlah nominal uang penukarannya dapat dipilih oleh pengguna menggunakan tombol yang ada pada mesin, sehingga sifat penukaran uang yang ada pada mesin ini sangat fleksibel karna pengguna dapat memilih sendiri berapa jumlah nominal uang kecil yang ingin mereka tukar. Saran untuk penelitian kedepannya adalah mesin dapat menukarkan uang dalam bentuk uang koin dan dapat dikembangkan untuk membaca keaslian dan nominal uang kertas rupiah yang baru, selain itu sistem dapat dikembangkan untuk mendeteksi berapa sisa jumlah nominal uang kecil yang tersisa didalam mesin.

\section{Daftar Pustaka}

[1] Abdul Jalil, "Nominal Exchange System Design Currency Rupiah's Using Image Pattern Recognition," International Conference on Computer Systems (ICCS) 2014 , pp. 1-6, 2014.

[2] Abdul Jalil, "Pengolahan Citra Mendeteksi Keaslian Uang Kertas Rupiah Menggunakan Raspberry Pi," Jurnal IT STMIK Handayani, vol. 14, pp. 28-40, 2014.

[3] Abdul Jalil, "Sistem Kontrol Deteksi Nominal Uang Kertas Rupiah Menggunakan Image Prosessing Raspberry Pi,“ Jurnal IT STMIK Handayani, vol. 14, pp. 13-19, 2014.

[4] Juliana, "Uang Dalam Pandangan Islam," Amwaluna, vol. 1, no. 2, pp. 217-230, 2017.

[5] S. Suprayitno, "Perancangan Desain Mata Uang Kertas Rupiah sebagai Kasus Wacana Redenominasi," Humaniora, vol. 5, no. 2, p. 698, 2014.

[6] A. Jalil, P. Wahyuningsih, "Penerapan Algoritma Greedy Pada Sistem Penukaran Nominal Mata Uang Rupiah," Konferensi Nasional IImu Komputer (KONIK), 2014.

[7] Abdul Jalil, "Mendeteksi Keaslian Uang Kertas Rupiah Dengan Metode Thresholding Menggunakan Raspberry Pi," Seminar Nasional Riset IImu Komputer (SNRIK), 2015.

[8] www.youtube.com, https://youtu.be/MFLVbKuWuDU. 